\title{
Peran Masyarakat Pesisir Bima Dalam Proses Masuknya Agama Islam Di Bima Pada Abad XVI-XVII
}

\author{
Roni Irawan ${ }^{1 \mathrm{a}^{*}}$ \\ STKIP Taman Siswa Bima \\ roniirawanstkip@gmail.com
}

Artikel Info

Tanggal Publikasi

2020-12-20

Kata Kunci

Peran Masyarakat pesisir

Islam di Bima

\section{Abstrak}

Penelitian ini bertujuan untuk mengetahui latar belakang masuknya agama Islam di bima, peranan msyarakat pesisit bima dalam proses masuknya agama islam di bima dan faktor pendorong masuknya agama islam di bima. Dalam penelitian ini teergolong penelitian sejarah dengan pendekatan deskriftif, metode penelitian sejarah yang digunakan adalah heuristik yaitu merupakan langkah pertama untuk mengumpulkan data-data awal untuk dijadikan sebagai sumber penelitian, Kritik yaitu untuk mencari keaslian sumber data, kritik internal dan eksternal, Intrepretasi yaitu menguraikan kembali dan menafsirkan setelah sumber data terkumpul dan dikritik, dan Historiografi yaitu tahap penulisan dari sebuah hasil penelitian. Berdasarkan hasil penelitian yaitu (1). Latar belakang masuknya agama islam di bima, tidak hanya dalam jalur perdagangan, tetapi masuknya agama islam di bima di bawah oleh Sunan Prampe dan para mubaliq yang datang daru Gowa, Tallo, Luwu dan Bone. Kedatangan para pedagang di bima tidak hanya untuk berdagang, melaikan memiliki misi untuk menyebarkan agama islam di bima. (2). Dalam proses masuknya agama islam di bima, masyarakat pesisir bima sangat berperan aktif dalam membantu para mubaliq dalam menyiarkan agama islam di bima, selain dari itu masyarakat pesisir bima yang berstatus sebagai pedagang sudah sejak awal membangun hubungan perdagangan yang baik dengan kerajaan-kerajaan di Nusantara seperti, Demak, Malaka, dan Sulawesi selatan. Kerajaan-kerajaan tersebut merupakan kerajaan yang memeluk dan memili misi dalam menyiarkan agama islam di bagian timur Nusantara Islam masuk di bima pada abad XVII M, yang dibawah oleh para pedagang-pedagang yang datang dari Gowa, Tallo, Luwu dan Bone yang berstatus sebagai mubaliq yang menyebarluaskan agama islam. (3).faktor yang mendorong masuknya agama islam di bima adalah faktor perdagangan dan dakhwah islamiyah para bubaliq dari Gowa, Tallo,Luwu dan Bone.

\section{PENDAHULUAN}

Daerah bima memiliki sejarah yang sangat panjang dalam proses masuknya Agama Islam. Kedatangan Islam di Bima abad ke $17 \mathrm{M}$, memberikan perubahan dan perkembangan yang sangat besar dalam kehidupan masyarakat bima dalam segi sosial dan budaya bagi masyarakat Bima. dalam kehidupan sosial pada awalnya masyarakat bima menganut kepacayaan lama yaitu kepercayaan terhadap Animisme dan Dinamisme (Makamba-Makimbi) serta memiliki kebudayaan yang sesuai dengan agama yang di anutnya.

Kepercayaan Animisme-Dinamisme (Makamba-makimbi) merupakan kepecayaan lama yang dianut dan diyakini dalam kehidupan sosial budaya Masyarakat Bima serta berkembang cukup lama dalam kehidupan masyarakat bima. Animisme - Dinamisme merupakan kepercayaan lama yang diwarisi secara turun temurun dari para leluhur masyarakat Bima. sebelum agama islam masuk di bima, masyarakat bima percaya terhadap roh-roh nenek moyang atau percayaan terhadap kekuatan-kekuatan gaib.

Perubahan jama dan perkembangan ilmu pengetahuan memberikan dampak yang sangat besar dalam perubahan keyakinan dan kepercayaan dalam setiap masyarakat. Keyakinan dan kepercayaan lama semakin hari semakin bergeser dengan agama-agama baru yang memiliki andil dalam memberikan suatu keyakinan yang snagat besar pengaruhnya dalam keehidupan beragama. Islam sebagai agama rahmmatal lillalmi. 
Masuknya agama islam di Bima pada abad ke-17 M. Merupakan awal masuknya agama islam di bima yang dibawa oleh para pedangang yang datang dari Gowa, Talo, Luwu dan Bone. Kedatangan para mubaliq dari Gowa, Talo, Luwu dan Bone merupakan utusan dari kerajaan yang ada di sulawesi selatan seperti kerajaan yang ada di Makasar untuk menyebar luaskan agama islam di Nusantara Bagian Timur, Daerah bima sala satu daerah yang menjadi tujuan utama untuk menyebarkan Agama Islam.

Kerajaan Bima dan Gowa, Talo, Luwu dan Bone memiliki hubungan yang sangat baik, sehingga para pedagang dan mubaliq yang datang di Bima diterima dengan baik oleh berbagai masyarakat bima yang tinggal di daerah pesisir Bima, hubungan yang baik ini memberikan dapak yang sangat positif dalam proses masuknya agama islam di Bima. Proses masuknya agama islam di bima dengan mudah di sebarluaskan karena kerajaan bima memiliki hubungan yang baik dengan kerajaan yang datang menyebarkan agama islam di bima.

Kedatangan para pedagang/mubaliq dari Gowa, Talo, Luwu dan Bone diterima dengan baik oleh masyarakat bima yang berada di pesisir bagian timur dan utara seperti masyarakat Sape, Wera, Wawonduru, dan Tambora. Masyarakat Bima yang tinggal di pesisi memiliki peran yang sangat besar dalam proses masuknya agama islam di Bima, dimana masyarakat pesisir bima membangun hubunga perdagangan dengan baik dengan para pedangan yang datang dari sulawesi selatan. Hal ini yang mendorong proses masuk islam di bima dengan secara damai, dengan menggunakan jalun perdagangan sebagai jalur penyebaran agama islam di Bima. Para pedagang yang datang dari Gowa, Talo, Luwu dan Bone selain berdangang juga sebagai mubaliq yang menyebarluaskan agama islam.

Pada awalnya masyarakat Bima yang tinggal dibagian pesisir Bima secara diam-diam sebagian masyarakat sudah memeluk agama islam, namun mereka merasa takut, karena kerajaan Bima belum memeluk agama islam sebagai agama yang dianutnya. Masyarakat pesisir memiliki perenan yang sangat besar dalam masuk dan berkembang agama islam di Bima, masyarakat pesisir membangun hubungan baik dengan para pedagang yang datang dari berbagai daerah di Nusantara, tetapi yang paling berperang dalam menyebarkan agama islam di Bima adalah orang-orang yang datang dari Sulawesi selatan yang datang untuk berdagang dan berstatus sebagai para mubaliq yang menyebarluaskan agama islam di bagian timur Nusantara.

Rombongan yang datang dari berbagai daerah di Sulawesi Selatan seperti orang-orang Luwu, Gowa, Tallo dan Bone. Rombongan tersebut tiba di Bima bagian pesisir Sape yang kenal sekarang dengan pelabuhan Sape pada tanggal 11 Jumadil awal 1038 H/1618 M. Rombongan itu berstatus sebagai pedangang muslim dan juga berstatus sebagai munaliq yang menyebarkan agama islam. Kedatangan mereka adalah membawa barang-barang daganganya seperti Ci'lo, Kain Bugis, disamping membawa surat resmi dari penguasa Bone untuk menguasai Sape Bima pada waktu itu. Dengan gelar Rumah Jena. Rombongan yang tiba di pelabuhan sape diutus secara resmi oleh penguasa yang di Sulawesi selatan untuk menguasai Nusantara bagian timur salah satunya untuk menguasa bima untuk dijadikan daerah untuk menyebarkan agama islam.

Proses penyebaran agama islam di bima cukup efektif, karena kedatangan orang-orang yang utusan dari Sulawesi selatan diterima dengan baik oleh masyarakat Bima. penyambutan yang baik oleh mesyarakat pesisir memberikan sinyal positif untuk memudahkan para mubaliq dalam menyebarkan agama islam di bima. terjalinya interaksi dalam ruang lingkup perdagangan banyak masyaraka bima yang bagian pesisir yang memeluk agama islam. Komunikasi perdangan itu menjadi sarana mengajak masyarakat bima masuk islam.

Masyarakat pesisir Sape lebih khsusunya memiliki perang yang penting dalam proses masuk dan berkembangnya Agama Isla | m di Bima, berdasarkan sumber kita "BO" bahwa masuknya agama islam di Bima pada tahun 1038 H/1618 M. Dan Sape merupakan tempat yang pertama yang didatangi oleh pera pedagang darii Gowa. Dan yang membawa agama islam di bima yang pertama adalah orang-orang yang berasal dari sulawesi selatan. Mereka datang menjajakan barang-barang dagangannya dan 
menyiarkan agama islam, meraka adala pedagang muslim, juga sebagai mubaliq yang menyiarkan agama islam di bebagai daerah-daerah yang meraka kunjungi.

Dalam proses islamisasi di bima masyarakat pesisir memiliki peran yang sangat besar untuk menyebarluaskan agama islam dibagian pedalaman bima, masyarakat sape mengajak para mubaliq untuk masuk dan bertemu dengan para ncuhi-ncuhi yang menguasai tiap-tiap daerah yang menjadi wilayah kekusaan Kearajaan Bima. berita kedatangan para mubaliq yang tiba di palabuahan sape tersebarluas di masyarakat bima sampai pada wilayah bima bagian pedalaman-pedalaman sape. Dua tahun kemudian para masyarakat pesisir Sape dan para mubaliq berhasil mengislamkan empat orang keluarga raja yang memeluk agama islam pertama di Bima. Pada mulanya, mereka tidak langsung memeluk agama islam, tetapi terlebih dahalu mempelajarinya sebelum mereka mengucapkan dua kalimat syahadat sebagai kesaksian memeluk agama islam. Kejadian tersebut dicatat dalam "BO" sebagai berikut: maka pada 10 hari bulan rabiul awal senat 1030 genap raja berempat itu mengucapkan dua kalimat syahadat dengan saksinya empat gurunya para mubaliq.

Setelah para mubaliq berhasil mengislamkan keempat keluarga raja, mereka pun kembali ke kalodu sebagai tempat pertama islam di terima secara resmi oleh kerajaan bima dengan mengucapkan dua kalimat syahadat. Tempat tersebut sebagai bukti sejarah perkembangan islam di bima. Masjid Kalodu sebagai bukti sejarah awal penerimaan agama islam di Bima dan kalodu sebagai tempat pertama masjid tertua di bangun di Bima.

Berita masuk Islam keempat keluarga raja Bima dengan cepat tersiar kemasyarakat diberbagai daerah pedalaman di bima, masyarakat berbondong-bondong ingin mengetahui ajaran baru dan sekaligus menerima agama islam sebagai agama yang dianutnya. Masyarakat pesisir bima tidak lagi menyembunyikan agama yang diyakini dan anutnya karena secara terbuka raja bima memerintahkan kepada seluruh masyarakat bima untuk menerima dan memeluk agama islam sebagai agama yang diyakini dan dianutnya. Semaki hari islam semakin berkembang masyarakat bima berbondongbondong memeluk agama islam, sehingga kerajaan bima beralih status dari sistem kerajaan menjadi sistem kesultanan.

Pengalihan status pemerintah ini menjadi bukti perkembangan islam di bima. pada awalnya masyarakat bima menganut sistem kerajaan dengan kepercayaan lama yang sebut dengan "makambamakakimbi" diganti dengan sistem pemerintahan kesultanan dengan kepercayaan baru agama islam sebagai agama yang dianutnya dalam kehidupan. Dalam sistem pemerintahan kesultanan bima berlandaskan syariat islam. Dengan terbentuk sistem kesultanan, islam semakin berjaya dan berkembang di bima, dimana dalam kehidupan sosial, budaya masyarakat bima berlandasarkan syariat islam.

\section{METODE PENELITIAN}

Metode yang digunakan dalam penelitian ini adalah metode historis dibantu dengan studi ddokumentasi, studi literatur dan wawancara sebagai tehnik penelitiannya. Metode sejarah digunakan untuk menguji dan menganalisis, secara kritis rekaman dan peninggalan masa lampau. (Gottschlak, 1986:32).

Metode histori merupakan cara untuk mengaji suatu peristiwa atau permasalahan yang dianggap layak dan penting yang terjadi pada masa lampau serta deskriptif, kritis dan analitis. Penulisan sejarah tidak hanya mengungkapkan peristiwa secara kronologis, lebih dari itu perlu adanya kajian dan analisis yang tajam yang didukung dengan teori yang relavan. Menurut Kuntowijoyo (2005:90) penelitian sejarah mempunyai lima tahap yaitu pemilihan topik, pengumpulan sumber, kritik sejarah, interpretasi dan historiografi. 


\section{HASIL DAN PEMBAHASAN}

\section{Latar Belakang Masuknya Agama Islam di Bima}

Perkembangan disektor pertanian yang berhasil diawali dalam masa pemerintahan Raja Manggampo Donggo, menjadikan daerah bima sebagai gudang beras dikawasan selatan. Sektor pertanian yang berperan sebagai mata rantai yang menghubungkan antara sumber rempah-rempah di Maluku dengan pasar internasional di Malaka menjadikan kedudukan bandar-bandar jawa amat penting. Perdagangan rempah-rempah semakin ramai dan menguntungkan, hal itu yang mengharuskan persediaan beras yang lebih banyak.

Kerajaan Bima sebagai daerah produksi beras di kawasan selatan mulai mendapatkan perhatian, dan wilayahnya sangat strategis yang terletak antara sulawesi selatan dan jawa. Kedudukan dan peran Kerajaan Bima semakin penting. Masyarakat pesisir Bima adalah masyarakat yang mempunyai hubungan perdagangan yang baik dengan Kerajaan Demak, Malaka, Sulawesi Selatan dan Ternate.

Latar belakang masuknya agama islam di bima, tidak hanya dalam jalur perdagangan, tetapi masuknya agama islam di bima di bawah oleh Sunan Prampe dan para mubaliq yang datang daru Gowa, Tallo, Luwu dan Bone. Kedatangan para pedagang di bima tidak hanya untuk berdagang, melaikan memiliki misi untuk menyebarkan agama islam di bima. yang mempuyai misi dalam menyebarluaskan Agama Islam di Bima. (Wawancara Yakub 20 Oktober 2020. Latar belakang masuknya agama islam di bima tidak hanya dalam jalur perdagangan tetapi latar belakang masuknya agama islam di bima antara misinya Sunan Prampe dan Sultan Makasar. (M. Facrin Racman, 2010.23).

Perdagangan rempah-rempah di selat malaka yang semakin ramai, mengharuskan kerajaan bima untuk menyediahkan beras yang lebih banyak. Produksi beras di jawa tidak mencukupi dalam kebutuhan pasar internasional, oleh karena itu kekurangan beras harus dicarikan di daerah lain, salah satunya adalah mencari di daerah bima. para pedangan muslim di jawa datang untuk berdagang dan membeli beras di bima.

Masuknya agama islam di bima dilatar belakangi oleh hubungan perdagangan yang dilakukan oleh para pedagang dari Demak, Malaka dan Sulawesi selatan. Para pedangan yang datang dari Demak dan Malaka mereka berstatus sebagai pedang maslim, tetapi hubungan peradagangan demak dan malaka tidak begitu berpenguh dalam perkembangan agama islam di bima. para pedangan dari Demak dan Malaka hanya berhasil mengislamkan sebagian masayarakat bima yang menjadi pedagang dan tinggal di bagian pesisir seperti masyarakat pesisir Sape, Tambora, Melayu dan Waworada dan tidak sampai mengislamkan keluarga Raja Bima.

Kedatangan para pedagang dari Sulawesi selatan seperti Gowa, Talo, Luwu dan Bone selain sebagai pedagang juga berstatus sebagai mubaliq untuk menyebarkan agama islam di bima. kedatantan para pedagang juga berstatus sebagai mubaliq diterima dengan baik oleh masyarakat pesisir Bima. sehingga proses islamisasi yang dilakukan oleh para mubaliq dengan mudah tampa ada hambata. Para mubaliq dari Gowa, Tallo, Luwu, dan Bone tidak hanya mengislam masyarakat pesisir saja, tetapi para mubaliq berhasil mengislamkan berbagai masyarakat bima dan kerajaan Bima.

Berita tentang kedatangan pada mubaliq dari Gowa, Tallo, Luwu dan Bone, tersebar luar ke daerah-daerah pedalaman Bima. Dua tahun kemudian di dengar oleh empat orang keluarga Raja, dan empat orang keluarga Raja merupakan pemeluk pertama Agama Islama di Bima. Pada awalnya mereka tidak langsung menerima agama islam, tetapi terlebih dahulu mempelajari sebelum mereka mengucapkan dua kalimat syahadat sebagai kesaksian memeluk agama islam. Kejadian tersebut di cata dalam "BO" Sangaji Kai. Pada 10 hari bula rabiul awal senat 1030 genap Raja berempat mengucapkan dua kalimat syahadat dan di saksi oleh empat orang para mubaliq. 


\section{Peranan Masyarakat Pesisir Bima dalam Masuknya Agama Islam di Bima}

Pada awalnya masyarakat bima mempunyai hubungan yang baik dengan berbagai kerajaan di Jawa dan Sulawasi selatan. Hubungan yang baik ini di awali dengan hubungan perdagang. Daerah bima adalah salah satu daerah yang sangat strategis dan memiliki penghasilan beras yang besar. Masyarakat bima mengeliligi daerah-daerah di Nusantara seperti Demak, Malaka, Samudra pasai dan Sulawasi selatan. Masyarakat bima berkunjung di berbagai daerah yang untuk berdagang, namun kemudian banyak masyarakat bima yang menetap mereka berdangang, begitu pula kedatangan para pedagangpedagang yang datang di Bima hanya untuk berdagang, namun dikemudian hari banyak yang menetap di berbagai daerah pesisir bima salah satunnya daerah pesisir sape. Bahkan sekarang para pedagang yang datang dari sulawesi selatan seperti Gowa, Tallo, Luwu dan Bone banyak yang menetap di Sape dan bahkan sudah mempunyai kampung sendiri seperi kampung Bugis dan Goa.

Dalam proses masunya agama islam di bima, masyarakat pesisir bima sangat berperan aktif dalam membantu para mubaliq dalam menyiarkan agama islam di bima, selain dari itu masyarakat pesisir bima yang berstatus sebagai pedagang sudah sejak awal membangun hubungan perdagangan yang baik dengan kerajaan-kerajaan di Nusantara seperti, Demak, Malaka, dan Sulawesi selatan. Kerajaankerajaan tersebut merupakan kerajaan yang memeluk dan memili misi dalam menyiarkan agama islam di bagian timur Nusantara. Dengan adanya hubungan perdagangan dengan para pedagang-pedagang yang bercorak islam masyarakat pesisir bima yang menjadi pedang sebagian sudah mengenal agama islam, walaupun agama islam belum diterima oleh masyarakat bima pada umumnya.

\section{Faktor yaang mendorong masuknya Agama Islam di Bima}

1. Faktor perdagangan

Kedatangan para pedagang dari berbagai daerah seperti Jawa, Gowa, Tallo,Luwu dan Bone memberikan dampak yang positif dalam proses masuknya agama islam di bima. rombongan yang datang dari Sulawesi selatan seperti Gowa, Tallo,Luwu dan Bone tiaba di pelabuhan Sape Bima pada tanggal 11 Jumaddil awal $1028 \mathrm{H} / 1618 \mathrm{M}$, sebagaimana yang dijelaskan rombongan tersebut berstatus sebagai pedagang sekalugus sebagai bulaiq yang menyebarkan agama islam di bima. kedatangan mereka membawa barang-barang dagang seperti kain cil'o, kain bugis. Kedatangan pada pedagang dari Gowa, Tallo,Luwu dan Bone selain berdagang juga membawa surat resmi dari penguasa Bone untuk menguasai Bima dan sekaligus menyebarkan agama islam di Bima.

Kerajaan Bima mempunyai hubungan baik dengan kerajaan-kerajaan yang ada di Sulawesi selatan seperti Gowa, Tallo,Luwu dan Bone. Hal ini yang menjadi faktor pendukung dalam proses masuknya agama islam di bima. kehadiran para pedagang dari Gowa, Tallo,Luwu dan Bone diterima dengan baik oleh masyarakat bima. hal tersebut yang meudahkan pada mubaliq dalam menyebarluaskan agama islam di bima. pada awalnya para mubaliq hanya mengislamkan masyarakat bima bagian pesisir seperi Sape, Wera, Sanggar, Tambora dan Waworada. Setelah para mubaliq berhasil mengislamkan masyarakat bima bagian pesisir, kemudian para mubaliq sedikir demi sedikit para mubaliq masuk pada bagian pedalaman, sehingga para mubaliq berhasil mengislamkan keluarga Raja Bima.

\section{Dakwah Islamiyah}

Kedatangan para mubaliq yang melakukan gakwah islamiyah untuk menyebarkan agama islam di bima, sebab para pedagang yang tiba di bagian pesisir bima, tidak hanya berdagang, melaikan menyebarluaskan agama islam di bima. para mubaliq yang tiba di pesisir sape merupakan utusan resmi dari penguasa makasar untuk menguasai dan mengislamkan masyarakat bima. pelabuha sape merupakan sala satu pelabuhan yang bisa menghubungkan jalur utara, sehingga jalur perdagangan menjadi ramai.

Faktor utama yang mendorng masuknya agama islam di bima adalah dakwah islamiyah atau seruan Amar Ma'ruf Nahir Munkar, hal ini terterah dalam surat resmi yang di kirim oleh penguasa 
keraajaan Gowa, yang merasa berkewajiban untuk menjalankan kebernaran dan mencegah kemungkaran, sedangkan faktor perdagangan merupakan alternatif sebagai faktor pelengkap.

\section{KESIMPULAN}

Berdasarkan hasil penelitian, maka kesimpulan dalam penelitian ini adalah sebegai berikut:

1. Islam masuk di bima malaui dua jalur yaitu jalu perdagangan dan jalur dakwah islamiah yang di lakuka oleh para mubaliq yang datang dari Sulawesi Selatan seperti Gowa, Tallo, Luwu dan Bone yang memiliki misi untuk menyebarkan agama islam di Bima. Gowa, Tallo, Luwu dan Bone mempunyai hubungan yang sangat baik dengan kerajaan Bima, hal ini yang memudahkan paa mubaliq menyebarkan agama islam di Bima.

2. Dalam proses masunya agama islam di bima, masyarakat pesisir bima sangat berperan aktif dalam membantu para mubaliq dalam menyiarkan agama islam di bima, selain dari itu masyarakat pesisir bima yang berstatus sebagai pedagang sudah sejak awal membangun hubungan perdagangan yang baik dengan kerajaan-kerajaan di Nusantara seperti, Demak, Malaka, dan Sulawesi selatan

3. Fakto yang mendorong masuknya agama islam di bima yaitu fakto pedangangan dan dakwah islamiyah, para pedagang yang datang tidak haya bestatus sebagai pedagang melaikan juga sebagai mubaliq yang menyebarkan Agama Islam.

\section{Daftar Pustaka}

Hartomo, 2009. Ilmu sosial dasar, Penerbit Bumi Aksara

Karto Dirjo, 1999. Metode Penggunaan Bahan. Penerbit. Remaja Rusdi Karya Jakarta.

Kasdin, 1993. Pengantar Ilmu Sejarah IKIP Universitas Surabaya

Luis Gottscal, 2006. Mengerti Sejarah. Penerbit Universitas Indonesia

M. Hillir Ismail, 2006. Kebangkitan Islam di Dana Mbojo. Penerbit. Binasti , 2007. Sejarah Dana Mbojo. Penerbit. Perun Villa Citra Bantar Jati. 